\title{
Effect of two dosages of Metarhizium anisopliae var. acridum against Rhammatocerus schistocercoides Rehn $^{(1)}$
}

\author{
Marcos Rodrigues de Faria ${ }^{(2)}$, Bonifácio Peixoto Magalhães ${ }^{(2)}$, Roberto Teixeira Alves ${ }^{(3)}$, \\ Francisco Guilherme Vergolino Schmidt(2), João Batista Tavares da Silva(2) and Heloísa Frazão(2)
}

\begin{abstract}
The fungus Metarhizium anisopliae var. acridum, strain CG 423, was tested under field conditions against the gregarious grasshopper Rhammatocerus schistocercoides (Rehn) (Orthoptera: Acrididae). Conidia formulated in a racemic mixture of soybean oil and kerosene were sprayed under field conditions using an ultralow-volume hand-held atomizer Ulva Plus adjusted to deliver $2.9 \mathrm{~L} / \mathrm{ha}$. Bands composed of $2^{\text {nd }}$ instar nymphs were treated with either $5.0 \times 10^{12}$ or $1.0 \times 10^{13}$ viable conidia/ha. The number of insects in each band was estimated at day one following spraying and by the end of the field trial (15 to 16 days posttreatment). Reductions in population size reached, in average, $65.8 \%$ and $80.4 \%$ for bands treated with the higher and lower dosage, respectively. For both dosages, total mortality rates of insects collected at two days post-application, and kept in cages for 14 days under lab conditions, showed no significant differences as compared to that obtained with insects collected immediately after spraying. Healthy insects were fed to native grasses sprayed on the field with $1.0 \times 10^{13}$ viable conidia/ha. Mortality levels of the nymphs fed on grasses collected two and four days post-application were not affected when compared to nymphs fed on grasses collected immediately following application.
\end{abstract}

Index terms: biological control, microbial pesticide, entomogenous fungus, grasshopper, oil formulation.

\section{Efeito de duas dosagens de Metarhizium anisopliae var. acridum contra Rhammatocerus schistocercoides Rehn}

\begin{abstract}
Resumo - O fungo Metarhizium anisopliae var. acridum, isolado CG 423, foi avaliado em condições de campo como agente de controle biológico do gafanhoto gregário Rhammatocerus schistocercoides (Rehn) (Orthoptera: Acrididae). Conídios formulados em uma mistura racêmica de óleo de soja e querosene foram pulverizados no campo com a utilização de um atomizador rotativo manual Ulva Plus, calibrado para aplicação de 2,9 L/ha. Bandos com ninfas de $2^{\circ}$ estádio foram tratados com o equivalente a 5,0x $10^{12}$ ou $1,0 \times 10^{13}$ conídios viáveis/ha. O número de insetos em cada bando foi estimado no $1^{\circ}$ dia após a aplicação e ao final do experimento (15 a 16 dias após tratamento). Reduções populacionais médias de $65,8 \%$ e $80,4 \%$ foram observadas nos bandos tratados com a maior e menor dosagem, respectivamente. Para as dosagens avaliadas, a mortalidade total de insetos coletados aos dois dias após a aplicação e mantidos em gaiolas durante 14 dias, no laboratório, não apresentou diferença significativa daquela obtida para insetos coletados imediatamente após a pulverização. Insetos sadios foram alimentados com gramíneas nativas pulverizadas no campo com 1,0x10 13 conídios viáveis/ha. As taxas de mortalidade observadas nas ninfas alimentadas com capim coletado aos dois e quatro dias após a pulverização não foram afetadas quando comparadas com ninfas alimentadas com capim coletado imediatamente após a pulverização.
\end{abstract}

Termos para indexação: controle biológico, pesticida microbiano, fungo entomopatogênico, gafanhoto, formulação oleosa.

\footnotetext{
(1) Accepted for publication on February 26, 2002.

${ }^{(2)}$ Embrapa-Centro Nacional de Pesquisa de Recursos Genéticos e Biotecnologia, Caixa Postal 02372, CEP 70849-970 Brasília, DF. E-mail: faria@ cenargen.embrapa.br, boni@cenargen.embrapa.br, schmidt@cenargen.embrapa.br, jtavares@cenargen.embrapa.br, heloisa@cenargen.embrapa.br

${ }^{(3)}$ Embrapa-Centro de Pesquisa Agropecuária dos Cerrados, Caixa Postal 08223, CEP 73301-970 Planaltina, DF. E-mail: ralves@cpac.embrapa.br
}

\section{Introduction}

Although biopesticides represent approximately $1.3 \%$ of the phytosanitary products used in the world, those directed to insect control have $4.5 \%$ of the market share for insecticides (Menn \& Hall, 1999). Products based on the bacterium Bacillus thuringiensis account for most of the sales, but those 
based on entomopathogenic fungi, specially the mitosporic group, have become very promising. In Brazil, production methods of entomopathogenic fungi were developed in the 70's (Aquino et al., 1977), and are based on rice as the substrate. The yields are relatively low and, for fungi such as Metarhizium anisopliae var. acridum and M. anisopliae var. anisopliae, vary from 2.5 to $6.0 \times 10^{9}$ conidia per gram under laboratory conditions (Quintela, 1994; Magalhães \& Frazão, 1996). As an additional disadvantage, conidia produced are not formulated, reducing the potential for longer shelflives and, therefore, turning production dependent on immediate demands.

In recent years, insect resistance to chemicals, high costs of research and development of new synthetic molecules, and technological breakthroughs on production, formulation and delivery of mycoinsecticides, have expanded the commercial success of these products (Wraight \& Carruthers, 1999). For example, the private company Mycotech (Butte, Montana, USA) has developed a diphasic fermentation system that allows an average yield of $2.6 \times 10^{10}$ conidia of Beauveria bassiana per gram on a proprietary substrate (Johnson et al., 1992). In addition, formulations based on oils (Thomas et al., 1996; Lomer et al., 1997; Milner et al., 1997) and adjuvant emulsifiable oils (Alves, 1999; Bateman $\&$ Alves, 2000) have proved suitable in many circumstances. Despite the mentioned advances, the balance between economically feasible rates and satisfactory control levels is delicate and, in some situations, responsible for failure cases of biological control programs based on entomopathogenic fungi. Studies carried out at field conditions aiming the establishment of appropriate dosages are critical in biological control programs involving biopesticides.

Until recently, the gregarious grasshopper Rhammatocerus schistocercoides was considered a severe pest in the Chapada dos Parecis, Mato Grosso State, Brazil, attacking rice, corn and sugarcane (Lecoq \& Pierozzi Junior, 1995a, 1995b; Miranda et al., 1996). This pest was chosen as a model system for a research project started in 1993 and aiming the microbial control of grasshoppers. Preliminary studies resulted in selection of the fungal pathogen $M$. anisopliae var. acridum, strain CG 423
(Moreira et al., 1996; Magalhães et al., 1997b) for deeper studies. A recent field trial performed at the permanent outbreak zone of $R$. schistocercoides resulted in outstanding mortality rate $(88 \%)$, demonstrating the fungus to be well suited for control strategies of grasshopper pests (Magalhães et al., 2000b). However, it was sprayed at a very high dosage, equivalent to $2.0 \times 10^{13}$ conidia/ha.

The objective of the present work, was to evaluate the effect of M. anisopliae var. acridum 1.0 $10^{13}$ and $5.0 \times 10^{12}$ conidia/hectare against the gregarious grasshopper Rhammatocerus schistocercoides (Rehn) (Orthoptera: Acrididae).

\section{Material and Methods}

\section{Fungal production and formulation}

Conidia of the strain CG 423 of M. anisopliae var. acridum were produced in parboiled rice according to the methodology described in Magalhães \& Frazão (1996). Conidia were transported to Campos de Júlio county (Mato Grosso State) as a powder, and added to a racemic mixture of soybean oil plus kerosene prior to field application.

\section{Selection of grasshopper bands}

Search for grasshopper bands was carried out for three days before first fungal application. Different sites were visited and all bands mapped. The accurate position of each band was recorded on a Global Positioning System. Nine bands, considered as having adequate sizes (between 120 and $600 \mathrm{~m}^{2}$ ), and located in areas far away from roads and, as much as possible, distant from other bands were selected. Information regarding the experimental area and procedures related to monitoring of grasshopper bands were previously reported (Magalhães et al., 2000b).

\section{Bioinsecticide application}

Red nozzle output and deposition tests using a handheld ULV spinning-disk atomizer, powered by six $1.5 \mathrm{~V}$ batteries, indicated the output to be $70 \mathrm{~mL}$ per minute, and the adequate spacing between swatches to be $4 \mathrm{~m}$. Walking speed of $1 \mathrm{~m} / \mathrm{s}$ and emission height of $1 \mathrm{~m}$ were adopted. Volume application rate was equivalent to $2.9 \mathrm{~L} / \mathrm{ha}$, and field dosages of $5.0 \times 10^{12}$ or $1.0 \times 10^{13}$ viable conidia/ha. For each dosage, 3 bands with most nymphs being on the $2^{\text {nd }}$ instar were treated. Bands treated with the low dosage $\left(5.0 \times 10^{12}\right)$ were designated as L1, L2 and 
L3, and those treated with the high dosage $\left(1.0 \times 10^{13}\right)$ were referred to as bands $\mathrm{H} 1, \mathrm{H} 2$ and $\mathrm{H} 3$. Spraying was limited to the surface area covered by each band, ranging from approximately 100 to $300 \mathrm{~m}^{2}$ at the time of spraying. Untreated bands (U1, U2 and U3) were considered as controls. Table 1 indicates the prevailing conditions by the time spraying was performed. Prior to application, conidial viability was determined according to methodology described by Magalhães et al. (1997a), and re-assessed following spraying. Bands were daily followed in their natural environment, from 15 (low dosage bands) to 16 days post-spraying (high dosage bands)

\section{Measuring size and density of bands}

Surface area and total number of nymphs per band were estimated at the beginning (day one) and by the end of the field trial. Surface area was determined by delimiting the band and dividing it in four different estimated density zones at day 1 post-spraying. The densities were 2,512, 696, 192, and 39 nymphs per $\mathrm{m}^{2}$, considered as extremely high, high, medium and low, respectively. Average numbers were obtained by throwing a metal barrel measuring $0.26 \mathrm{~m}^{2}$ on specific density zones within bands and counting the number of captured insects. The total number of nymphs per band was determined by multiplying the surface area of each density zone by the correspondent number of nymphs per $\mathrm{m}^{2}$, and adding the values up. Since the average number of nymphs per density zones changed according to nymphal instar, number of individuals in a given band was overestimated by the end of the experiment, when band sizes had increased due to molting of nymphs to $3^{\text {rd }}$ instar. Nymphal mortality due to natural factors in control bands was expected to be low, equivalent to a theoretical value of $0.86 \%$ a day (Miranda et al., 1996), which turns out to correspond to $13.8 \%$ after 16 days. This value was confirmed in a field trial carried out in 1998 (Magalhães et al., 2000b), when a mortality rate of $13.1 \%$ was observed after 14 days. Numbers calculated at the end of the field trial for treated bands were adjusted considering the expected natural mortality $(0.86 \%$ per day) and the increasing size constant (ISC) derived from observations of untreated bands. The constant (ISC $=2.19)$ was obtained by dividing the average number of insects in untreated bands estimated at the final and beginning of the trial. Distances daily traveled by bands were measured as well.

\section{Caged insects}

For each conidial dosage, nymphs were collected at zero, two and four days post-spraying of the fungus. For untreated bands, insects were collected only at the beginning of the experiment. Groups of 30 insects were kept in cages and fed to native grass Andropogon selloanus Hackel, which was replaced every other day. Insects were daily observed and dead insects placed on a moist chamber in order to confirm if death was caused by M. anisopliae var. acridum. Insects showing the typical red coloration or external mycelial growth on the cadaver were considered as killed by the pathogen.

In a second experiment with caged insects, the persistence of the fungus $M$. anisopliae var. acridum when sprayed on vegetation at a dosage equivalent to $1.0 \times 10^{13}$ conidia/ha was studied. Grass leaves collected at a sprayed site, immediately after, two and four days following spraying, were offered to healthy nymphs kept in cages. Total percentage of deaths and confirmed mortality rates were then determined. Each treatment comprised three replicates, and insects were kept under laboratory conditions for 14 days. In the last experiment, nymphs were collected 11 days post-spraying within spots of band $\mathrm{H} 1 / \mathrm{H} 2$ presenting extremely high, high, medium and low nymphal densities. Insects were kept under laboratory conditions for seven days, then the cumulative total and confirmed mortality levels were recorded. Only one replicate was performed per class of nymphal density.

Table 1. Parameters prevailing during spraying of fungus Metarhizium anisopliae var. acridum against the hopper Rhammathocerus schistocercoides under field conditions.

\begin{tabular}{|c|c|c|c|c|c|c|}
\hline \multirow[t]{2}{*}{ Parameters } & \multicolumn{6}{|c|}{ Hopper band $^{(1)}$} \\
\hline & L1 & $\mathrm{L} 2$ & L3 & $\mathrm{H} 1$ & $\mathrm{H} 2$ & H3 \\
\hline Date & November, 29th & November, 29th & November, 29th & November, 28th & November, 28th & November, 28th \\
\hline Time (h) & $16: 35 / 16: 43^{(2)}$ & $17: 37 / 17: 44$ & $18: 26 / 18: 39$ & $16: 55 / 17: 05$ & $17: 43 / 17: 52$ & $18: 26 / 18: 35$ \\
\hline Temperature $\left({ }^{\circ} \mathrm{C}\right)$ & $27.4 / 24.9$ & $23.0 / 23.4$ & $22.4 / 22.4$ & $25.9 / 24.1$ & $23.3 / 22.6$ & $22.4 / 22.0$ \\
\hline Average wind speed $\left(\mathrm{ms}^{-1}\right)$ & $1.2 / 2.0$ & $0.9 / 0.9$ & $1.3 / 1.1$ & $<0.5 / 1.3$ & $2.9 / 1.2$ & $0.7 / 1.2$ \\
\hline Light intensity (lux) & $227 \times 10^{2} / 66 \times 10^{2}$ & $16.4 \times 10^{2} / 10.9 \times 10^{2}$ & $30 / 0$ & $261 \times 10^{3} / 176 \times 10^{2}$ & $63 \times 10^{2} / 20 \times 10^{2}$ & $2 \times 10^{2} / 1.3$ \\
\hline Other & Cloudy, light rain & Cloudy, light rain & $\begin{array}{l}\text { Cloudy, light rain } \\
2 \text { minutes before } \\
\text { spraying }\end{array}$ & $\begin{array}{l}\text { Cloudy, it stopped } \\
\text { raining } 40 \text { minutes } \\
\text { before spraying }\end{array}$ & Cloudy & Cloudy \\
\hline
\end{tabular}

${ }^{(1)} \mathrm{L} 1, \mathrm{~L} 2, \mathrm{~L} 3$ and H1, H2, H3: hopper bands treated with low dosage (5.0x1012 conidia/ha) and high dosage (1.0x10 ${ }^{13}$ conidia/ha) of M. anisopliae var. acridum.

${ }^{(2)}$ Numbers before and after slash refer to prevailing conditions at the beginning and at the end of the spraying period, respectively. 


\section{Analyses}

Although there were three treated bands for each application rate at day one, the number of bands was reduced to two due to merging of bands along the period. Therefore, statistical analyses were not performed for the field trial. Regarding laboratory assays, percentage data were submitted to one way analysis of variance, and average comparisons were done with $\mathrm{t}$ test or Tukey at a 5\% significance level. The software SigmaStat (Kuo et al., 1992) was employed for the statistical procedures.

\section{Results and Discussion}

One day prior to application, viability of pure conidia of Metarhizium anisopliae var. acridum was $89 \%$. Following spraying, viability of conidia formulated in the racemic mixture of soybean oil and kerosene was re-assessed and showed no reduction.

No significant differences in total mortality were observed immediately following application, two or four days post-spraying ( $\mathrm{t}$ test; $\mathrm{P} \geq 0.145$ ) when the two dosages were compared under laboratory conditions (Table 2). A different trend was observed for confirmed mortality, since at immediately following application and two days post-application the averages for treatment with $5.0 \times 10^{12}$ conidia/ha were significantly higher $(\mathrm{P} \leq 0.038)$ than four days post-application.
For the low dosage, total mortality average of nymphs collected at day four post-spraying was significantly reduced (Tukey; $\mathrm{P}=0.004$ ). For the high dosage, no differences were observed among averages $(\mathrm{P}=0.330)$. Regarding confirmed mortality, for both dosages the differences among averages were not significant $(\mathrm{P} \geq 0.080)$. According to Vicentini \& Magalhães (1996), events related to attachment, germination and penetration of strain CG 423 into the host take place in 18 hours. The results demonstrate that the invasive capability of conidia exposed to environmental constraints for at least two days is not being severely affected.

No significant differences in either total mortality or confirmed mortality under laboratory conditions were found when nymphs were fed on grasses collected immediately following application, two and four days post-spraying $(\mathrm{P}=0.167$ and 0.056 for total and confirmed mortality, respectively), although there is a trend of grasses collected at day four to induce lower mortality levels (Table 3). During the trial period and, specially, until two days post-spraying, UV radiation and other detrimental factors did not play a major role in conidia inactivation. The oil formulation may have some contribution to this persistence, as previously reported in other studies (Moore et al., 1993; Alves et al., 1998). Besides, climatic condition at Campos de Júlio county during the field trial, characterized by mild temperatures, high relative humid-

Table 2. Percentage of mortality of the hopper Rammatocerus schistocercoides nymphs collected at various times following field application of fungus Metarhizium anisopliae var. acridum (5.0x $10^{12}$ and $1.0 \times 10^{13}$ conidia/ha) and kept under laboratory conditions for 14 days.

\begin{tabular}{|c|c|c|c|c|c|c|}
\hline \multirow[t]{2}{*}{ Replicate $^{(1)}$} & \multicolumn{3}{|c|}{ Total mortality } & \multicolumn{3}{|c|}{ Confirmed mortality } \\
\hline & Day 0 & Day 2 & Day 4 & Day 0 & Day 2 & Day 4 \\
\hline & \multicolumn{6}{|c|}{$5.0 \times 10^{12}$} \\
\hline 1 & 80.0 & 85.2 & 70.0 & 66.7 & 70.4 & 60.0 \\
\hline 2 & 85.7 & 93.1 & 50.0 & 71.4 & 65.5 & 23.3 \\
\hline 3 & 85.7 & 85.2 & 53.3 & 52.4 & 55.6 & 20.0 \\
\hline Average $^{(2)}$ & $83.8 \pm 1.90 \mathrm{a}$ & $87.8 \pm 2.63 \mathrm{a}$ & $57.8 \pm 6.19 \mathrm{a}$ & $63.5 \pm 5.71 \mathrm{a}$ & $63.8 \pm 4.35 \mathrm{a}$ & $34.4 \pm 34.4 \mathrm{a}$ \\
\hline & \multicolumn{6}{|c|}{$1.0 \times 10^{13}$} \\
\hline 1 & 53.3 & 80.8 & 66.7 & 30.0 & 30.8 & 50.0 \\
\hline 2 & 66.7 & 64.3 & 66.7 & 50.0 & 35.7 & 36.7 \\
\hline 3 & 83.3 & 86.2 & 46.7 & 33.3 & 13.8 & 23.3 \\
\hline Average & $67.8 \pm 8.68 \mathrm{a}$ & $77.1 \pm 6.59 \mathrm{a}$ & $60.0 \pm 6.67 \mathrm{a}$ & $37.8 \pm 6.19 b$ & $26.8 \pm 6.64 b$ & $36.7 \pm 7.71 \mathrm{a}$ \\
\hline
\end{tabular}

(1) Insects from replicates 1,2 and 3 of treatments $5.0 \times 10^{12}$ and $1.0 \times 10^{13}$ were collected from bands L1, L2, L3 and H1, H2 and H3, respectively. ${ }^{(2)}$ In a given column, average numbers \pm standard error followed by the same letter are not significantly different according to t test $(\alpha=0.05)$; average total and confirmed mortality rates for the control were $21.1 \pm 7.76 \%$ and $0 \%$, respectively. 
ity and intense cloudiness (Table 1), was an important factor that contributed to the satisfactory performance of the fungus. The persistence of $M$. anisopliae var. acridum on the foliage probably increases the level of fungal infection due to secondary pickup, but so far the role of this process was not addressed in our trials.

In the field, one band of the low dosage (L1) merged with an untreated band on December $2^{\text {nd }}$ and it was not considered thereafter. Two treated bands of the high dosage ( $\mathrm{H} 1$ and $\mathrm{H} 2)$ merged three days following spraying, and were considered altogether since then. The merging of bands is a natural phenomenon in areas presenting high density of bands, explained by their considerable mobility. In some instances, $2^{\text {nd }}$ instar nymphs were recorded moving as fast as $100 \mathrm{~m}$ a day.

Population reduction of $R$. schistocercoides nymphs at the end of the experiment ranged from 81.7 to $84.1 \%$ for the low dosage bands (L1 and L3) and from 61.6 to $79.6 \%$ for the high dosage bands (H1/H2 and H3). Interestingly, the light rain during application time of bands L1 and L2, and wet vegetation during spraying of bands $\mathrm{L} 3$ and $\mathrm{H} 1$, did not hamper the achievement of satisfactory control levels. In contrast to studies in which water-based formulations were used (Inglis et al., 1995), precipitation seems not to considerably reduce the attachment of oil-formulated conidia to hydrophobic surfaces, specially grasshopper cuticles and grass parts. An illustrative diagram of the structural changes in an untreated and treated bands is shown in Figure 1.
The values are close to the $88 \%$ reduction obtained in the 1998 field trial when a dosage equivalent to $2.0 \times 10^{13}$ conidia/ha was applied (Magalhães et al., 2000b). The results clearly suggest that economically feasible dosages (a quarter of that used in 1998) have a significant impact on grasshopper populations. Different studies have shown the possibility of achieving high control levels under field conditions applying dosages as low as $1.0 \times 10^{12}$ to $3.0 \times 10^{12}$ conidia/ha (Hooper et al., 1995; Price et al., 1997). Worldwide, the use of fungi for regulation of grasshopper populations is a successful biological control strategy and reviews on this subject can be found elsewhere (Goettel, 1992; Lomer, 1997; Magalhães et al., 2000a). Reports claiming successful control of other pests using field rates lower than $5.0 \times 10^{12}$ conidia/ha are rare, mainly in open field environments, moreover in semi-arid regions.

To date, it is not known if $R$. schistocercoides is able to thermoregulate (capability of controlling body temperature through active physiological or behavioral mechanisms), as observed for Melanoplus sanguinipes (Boorstein \& Ewald, 1987), Taeniopoda eques (Whitman, 1988) and many other species (Chappell \& Whitman, 1990). It is clear that during the rainy season, when the nymphal stage occurs and maximum temperatures are around $30^{\circ} \mathrm{C}$, any increase in body temperature is not being able to deter the fungal infection. In fact, during the peak of the epizootics, usually from 11 to 14 days post-spraying, dead insects were found in stem grasses in a basking position.

Table 3. Percentage of mortality of the hopper Rammatocerus schistocercoides nymphs fed on native grass sprayed with Metarhizium anisopliae var. acridum (1.0x10 13 viable conidia/ha).

\begin{tabular}{|c|c|c|c|c|c|c|}
\hline \multirow[t]{3}{*}{ Replicate } & \multicolumn{6}{|c|}{ Days after spraying } \\
\hline & \multicolumn{3}{|c|}{ Total mortality } & \multicolumn{3}{|c|}{ Confirmed mortality } \\
\hline & Day $0^{(1)}$ & Day 2 & Day 4 & Day 0 & Day 2 & Day 4 \\
\hline 1 & 63.3 & 96.7 & 70.0 & 43.3 & 46.7 & 10.0 \\
\hline 2 & 57.9 & 77.8 & 36.7 & 36.8 & 38.9 & 20.0 \\
\hline 3 & $-(2)$ & 61.9 & 20.0 & $-(2)$ & 19.0 & 10.0 \\
\hline Average $^{(3)}$ & $60.6 \pm 1.90 \mathrm{a}$ & $78.8 \pm 2.63 a$ & $42.2 \pm 6.19 \mathrm{a}$ & $40.1 \pm 5.71 \mathrm{a}$ & $34.9 \pm 4.35 \mathrm{a}$ & $13.3 \pm 34.4 \mathrm{a}$ \\
\hline
\end{tabular}


In the field trial the distances daily traveled by treated nymphs, when compared to untreated insects, were not severely affected. During the first eight days, average distances daily traveled in the control, and treatments with $5.0 \times 10^{12}$ and $1.0 \times 10^{13}$ conidia/ha were $43.0 \pm 4.77,38.5 \pm 2.90$ and $53.3 \pm 16.75 \mathrm{~m}$, respectively (Figure 2). From eight days post-spraying to the end of the experiment, nymphs from the control moved $41.7 \mathrm{~m}$ a day, on average. In contrast, treated nymphs reduced the traveled distance to 29.0 and $38.8 \mathrm{~m}$ a day, respectively. Studies carried out under laboratory conditions have demonstrated that sixth instar $R$. schistocercoides nymphs topically inoculated with 5,000 conidia of $M$. anisopliae var. acridum (CG 423) presented a significant reduction in food intake from day three onward (Faria et al.,

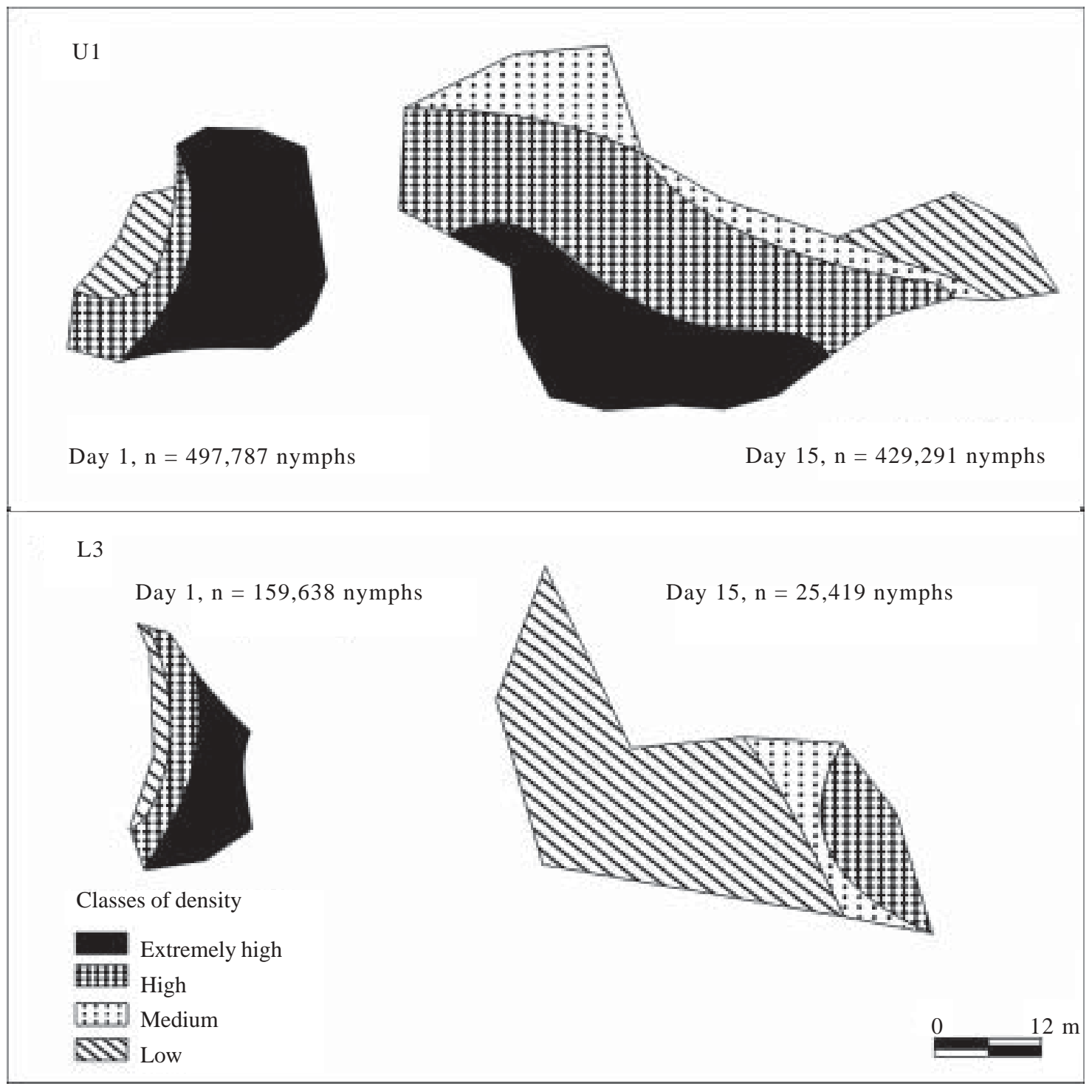

Figure 1. Illustrative diagrams of untreated (band U1) and fungus-treated (L3) bands of Rhammatocerus schistocercoides at the beginning (day 1) and end (day 15) of the field trial. 
1999). The authors also observed that treated insects were less mobile than healthy ones and usually succumbed to fungal infection before the $10^{\text {th }}$ day. There are some reasons that may explain the relatively long distances moved by treated nymphs under field conditions: conidial dose effectively delivered to each nymph is much lower than 5,000; and, nymphs were always collected in the front line of the bands, characterized for the high density of fast moving grasshoppers. The sampling procedure was biased toward fast moving nymphs, the ones that were less affected by the fungus. In order to solve this doubt, nymphs were collected 11 days post-spraying within spots of band $\mathrm{H} 1 / \mathrm{H} 2$ with extremely high (front line), high, medium and low nymphal density (Table 4). Mortality rates observed in medium and low density spots were considerably higher, corroborating the hypothesis that sick nymphs, incapable of following healthy ones, tend to be found in low density zones (the ones located in the back of the band).

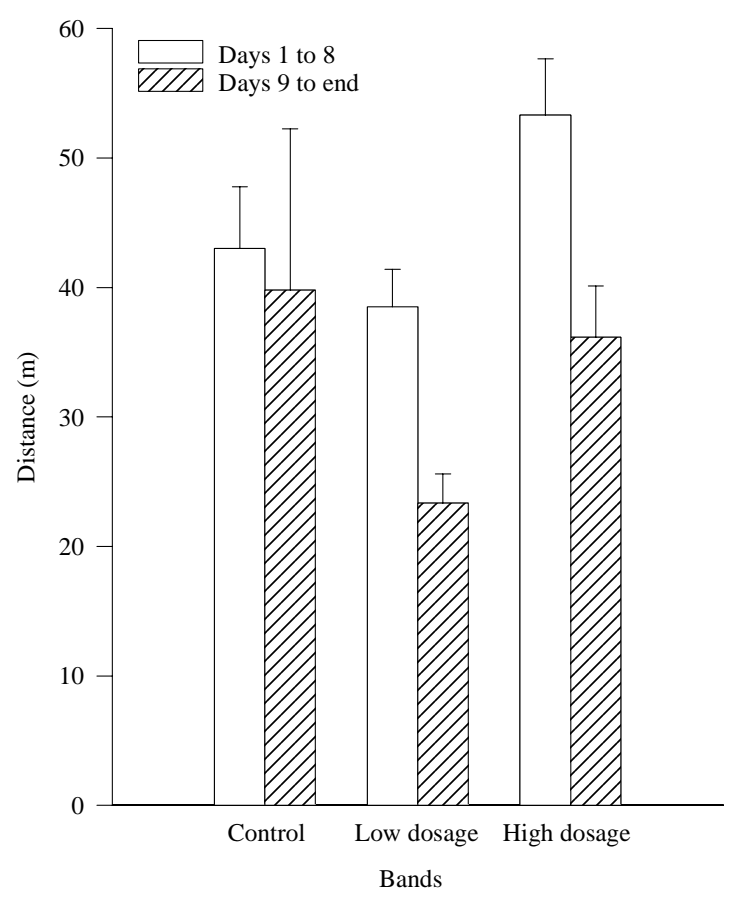

Figure 2. Average distances daily traveled by bands of grasshopper nymphs, Rhammatocerus schistocercoides, treated with low $\left(5.0 \times 10^{12}\right)$ and high $\left(1.0 \times 10^{13}\right.$ conidia/ha) dosage of fungus Metarhizium anisopliae var. acridum.
Table 4. Percent mortality rates of the hopper Rhammatocerus schistocercoides nymphs collected in different density zones within a treated band at 11 days postspraying with fungus Metarhizium anisopliae var. acridum and caged for seven days.

\begin{tabular}{lrrrr}
\hline \multirow{2}{*}{$\begin{array}{c}\text { Mortality } \\
\text { Total }\end{array}$} & \multicolumn{4}{c}{ Density zone ${ }^{(1)}$} \\
\cline { 2 - 5 } & $\begin{array}{c}\text { Extremely } \\
\text { high }\end{array}$ & High & Medium & Low \\
\hline Total & 22.0 & 24.0 & 95.0 & 84.1 \\
Confirmed & 2.0 & 4.0 & 30.0 & 27.3 \\
\hline
\end{tabular}

${ }^{(1)}$ Densities zones extremely high, high, medium and low correspond to 2,512, 696, 192 and 39 nymphs per $\mathrm{m}^{2}$, respectively.

In fact, in the second half of the trial it was common to find groups of sluggish nymphs, not responsive to humans approximation. It was possible to observe a high number of spiders, ants and Calosoma sp. (Coleoptera: Carabidae) preying on $R$. schistocercoides nymphs. In the last days there were hundreds of reddish dead bodies on tracks of the treated bands, whereas this did not happen in the control treatment.

This study provides additional evidences for use of $M$. anisopliae var. acridum as mycoinsecticide for grasshopper control. Field trials to test other dosages and the impact of the fungus on non-target organisms are under way.

\section{Conclusions}

1. Nymphs of $R$. schistocercoides are susceptible to field dosages of $M$. anisopliae var. acridum as low as $5.0 \times 10^{12}$ conidia/ha.

2. Mortality rates for nymphs collected up to two or four days post-spraying are not affected when the dosages $5.0 \times 10^{12}$ conidia/ha and $1.0 \times 10^{13}$ conidia/ha are applied.

3. High mortality rates for nymphs fed to grasses treated with $M$. anisopliae var. acridum, up to four days post-treatment, reinforce the argument that persistency of the fungus in the field is not severely affected by adverse environmental conditions at Campos de Júlio, MT.

\section{Acknowledgements}

To Neri Guilherme Haltmann and Milton Przypysz from Associação Alcooleira de Mato Grosso S.A. 
(Alcomat), Campos de Júlio, MT, for the logistic help that became possible the accomplishment of this work; the second author thanks to $\mathrm{CNPq}$ (Conselho Nacional de Desenvolvimento Científico e Tecnológico) for a productivity award.

\section{References}

ALVES, R. T. Development of mycoinsecticide formulations and application techniques appropriate for pest control. 1999. 225 p. Thesis (Ph.D.) - University of London, London, 1999.

ALVES, R. T.; BATEMAN, R. P.; PRIOR, C.; LEATHER, S. R. Effects of simulated solar radiation on conidial germination of Metarhizium anisopliae in different formulations. Crop Protection, Surrey, v. 17, n. 8, p. 675-679, 1998.

AQUINO, M. L. N.; VITAL, A. F.; CAVALCANTI, V. L. B.; NASCIMENTO, M. G. Cultura de Metarhizium anisopliae (Metsch.) Sorokin em sacos de polipropileno. Boletim Técnico CODECAP, Recife, v. 5, p. 7-11, 1977.

BATEMAN, R. P.; ALVES, R. T. Delivery systems for mycoinsecticides using oil-based formulations. Aspects of Applied Biology, Guildford, v. 57, p. 163-170, 2000.

BOORSTEIN, S. M.; EWALD, P. W. Costs and benefits of behavioral fever in Melanoplus sanguinipes infected by Nosema acridophagus. Physiological Zoology, Chicago, v. 60, n. 5, p. 586-595, 1987.

CHAPPELL, M. A.; WHITMAN, D. W. Grasshopper thermoregulation. In: CHAPMAN, R. F.; JOERN, A. (Ed.). Biology of grasshoppers. New York: Wiley Interscience, 1990. p. 143-157.

FARIA, M. R. de; ALMEIDA, D. de O.; MAGALHÃES, B. P. Food consumption of Rhammatocerus schistocercoides Rehn (Orthoptera: Acrididae) infected by the fungus Metarhizium flavoviride Gams \& Rozsypal. Anais da Sociedade Entomológica do Brasil, Londrina, v. 28, n. 1, p. 91-99, mar. 1999.

GOETTEL, M. S. Fungal agents for biocontrol. In: LOMER, C. J.; PRIOR, C. (Ed.). Biological control of locusts and grasshoppers. Wallingford: CAB International, 1992. p. 122-132.

HOOPER, G. H. S.; MILNER, R. J.; SPURGIN, P. A.; PRIOR, C. Initial field assessment of Metarhizium flavoviride Gams and Rozsypal (Deuteromycotina: Hyphomycetes) for control of Chortoicetes terminifera
(Walker) (Orthoptera: Acrididae). Journal of the Australian Entomological Society, Brisbane, v. 34, p. 83-84, 1995.

INGLIS, G. D.; JOHNSON, D. L.; GOETTEL, M. S. Effects of simulated rain on the persistence of Beauveria bassiana conidia on leaves of alfalfa and wheat. Biocontrol Science and Technology, Abingdon, v. 5, p. 365-369, 1995.

JOHNSON, D. L.; GOETTEL, M. S.; BRADLEY, C. A.; PAAUW, H. van der; MAIGA, B. Field trials with the entomopathogenic fungus Beauveria bassiana against grasshoppers in Mali, West Africa. In: LOMER, C. J.; PRIOR, C. (Ed.). Biological control of locusts and grasshoppers. Wallingford: CAB International, 1992. p. 298313.

KUO, J.; FOZ, E.; MacDONALD, S. Sigmastat: statistical software for working scientists. San Francisco: Jandel Scientific, $1992.747 \mathrm{p}$.

LECOQ, M.; PIEROZZI JUNIOR, I. Le criquet du Mato Grosso: 1'agriculture est-elle responsable? Tropicultura, Brussels, v. 13, p. 32-33, 1995a.

LECOQ, M.; PIEROZZI JUNIOR, I. Rhammatocerus schistocercoides locust outbreaks in Mato Grosso (Brazil): a long-standing phenomenon. The International Journal of Sustainable Development and World Ecology, Carnforth, v. 2, p. 45-53, 1995 b.

LOMER, C. J. Metarhizium flavoviride: recent results in the control of locusts and grasshoppers. In: KRALL, S.; PEVELING, R.; DIALLO, D. B. (Ed.). New strategies in locust control. Basel: Birkhäuser, 1997. p. 159-169.

LOMER, C. J.; PRIOR, C.; KOOYMAN, C. Development of Metarhizium spp. for the control of grasshoppers and locusts. Memoirs of the Entomological Society of Canada, Ottawa, v. 171, p. 265-286, Nov. 1997.

MAGALHÃES, B.; FARIA, M.; FRAZÃO, H. A technique to estimate the conidial viability of Metarhizium flavoviride Gams \& Rozsypal (Hyphomycetes) formulated in vegetable oil. Anais da Sociedade Entomológica do Brasil, Londrina, v. 26, n. 3, p. 569-572, dez. 1997a.

MAGALHÃES, B. P.; FARIA, M. R. de; SILVA, J. B. T. da. Controle microbiano de gafanhotos. In: MELO, I. S. de; AZEVEDO, J. L. de (Ed.). Controle biológico. Jaguariúna: Embrapa-CNPMA, 2000a. v. 2, p. 173-211.

MAGALHÃES, B. P.; FARIA, M.; TIGANO, M. S.; SOBRAL, B. W. S. Characterization and virulence of a 
Brazilian isolate of Metarhizium flavoviride Gams \& Rozsypal (Hyphomycetes). Memoirs of the Entomological Society of Canada, Ottawa, v. 171, p. 313-321, Nov. 1997b.

MAGALHÃES, B. P.; FRAZÃO, H. S. Effects of temperature, water content and substrate on conidial production of Metarhizium flavoviride. Revista de Microbiologia, São Paulo, v. 27, p. 242-246, 1996.

MAGALHÃES, B. P.; LECOQ, M.; FARIA, M. R. de; SCHMIDT, F. G. V.; GUERRA, W. D. Field trial with the entomopathogenic fungus Metarhizium anisopliae var. acridum against bands of the grasshopper Rhammatocerus schistocercoides in Brazil. Biocontrol Science and Technology, Abingdon, v. 10, p. 427-441, 2000b.

MENN, J. J.; HALL, F. R. Biopesticides: present status and future prospects. In: MENN, J. J.; HALL, F. R. (Ed.). Biopesticides: use and delivery. Totowa: Humana, 1999. p. 1-10.

MILNER, R. J.; BAKER, G. L.; HOOPER, G. H. S.; PRIOR, C. Development of a mycoinsecticide for the Australian plague locust. In: KRALL, S.; PEVELING, R.; DIALLO, D. B. (Ed.). New strategies in locust control. Basel: Birkhäuser, 1997. p. 177-183.

MIRANDA, E. E.; LECOQ, M.; PIEROZZI JUNIOR, I.; DURANTON, J. F.; BATISTELLA, M. O gafanhoto do Mato Grosso: balanço e perspectivas de 4 anos de pesquisas - 1992-1996. Montpellier: Centre de Coopération Internationale en Recherche Agronomique pour le Développement, 1996. 146 p. Relatório final do projeto Meio Ambiente e Gafanhotos Pragas do Brasil.

MOORE, D.; BRIDGE, P. D.; HIGGINS, P. M.; BATEMAN, R. P.; PRIOR, C. Ultra-violet radiation damage to Metarhizium flavoviride conidia and the protection given by vegetable and mineral oils and chemical sunscreens. Annals of Applied Biology, Cambridge, England, v. 122, p. 605-616, 1993.
MOREIRA, A. B.; MAGALHÃES, B. P.; VALADARES, M. C. C.; CHAGAS, M. C. M. Occurrence of Metarhizium flavoviride Gams \& Rozsypal (Hyphomycetes) on Schistocerca pallens (Thunberg) (Orthoptera: Acrididae) in Rio Grande do Norte, Brazil. Anais da Sociedade Entomológica do Brasil, Londrina, v. 25, p. 359-361, ago. 1996.

PRICE, R. E.; BATEMAN, R. P.; BROWN, H. D.; BUTLER, E. T.; MÜLLER, E. J. Aerial spray trials against brown locust (Locustana pardalina, Walker) nymphs in South Africa using oil-based formulations of Metarhizium flavoviride. Crop Protection, Surrey, v. 16, p. 345-351, 1997.

QUINTELA, E. Produção de Metarhizium anisopliae (Metsch.) Sor. em quirela de arroz. Anais da Sociedade Entomológica do Brasil, Londrina, v. 23, p. 557-560, dez. 1994.

THOMAS, M. B.; LANGEWALD, J.; WOOD, S. N. Evaluating the effects of a biopesticide on populations of the variegated grasshopper, Zonocerus variegatus. Journal of Applied Entomology, Hamburg, v. 33, p. 15091516, 1996.

VICENTINI, S.; MAGALHÃES, B. P. Infection of the grasshopper, Rhammatocerus schistocercoides Rehn by the entomopathogenic fungus, Metarhizium flavoviride Gams \& Rozsypal. Anais da Sociedade Entomológica do Brasil, Londrina, v. 25, p. 309-314, ago. 1996.

WHITMAN, D. W. Function and evolution of thermoregulation in the desert grasshopper Taeniopoda eques. Journal of Animal Ecology, Oxford, v. 57, p. 369-383, 1988.

WRAIGHT, S. P.; CARRUTHERS, R. I. Production, delivery, and use of mycoinsecticides for control of insect pests on field crops. In: MENN, J. J.; HALL, F. R. (Ed.). Biopesticides: use and delivery. Totowa: Humana, 1999. p. 233-269. 